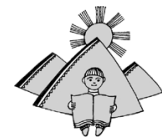

doi: 10.15330/msuc.2019.21.103-107

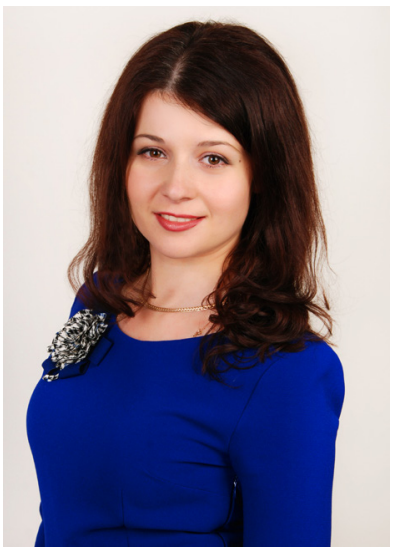

\author{
Скоморовська Ірина,
}

кандидат педагогічних наук, доцент кафедри

теорії та методики дошкільної та спеціальної освіти, ДВНЗ «Прикарпатський національний університет імені Василя Стефаника» (м. Івано-Франківськ, Україна)

\author{
Skomorovska Iryna, \\ Candidate of pedagogical sciences (PhD), \\ Associate Professor, \\ Vasyl Stefanyk Precarpathian National university \\ (Ivano-Frankivsk, Ukraine) \\ irynaskomorovska@pu.if.ua \\ ORCID ID 0000-0001-7617-9877
}

удк 373.24

\title{
РОЗВИТОК ТВОРЧОСТІ ДОШКІЛЬНИКІВ У РІЗНИХ ВИДАХ ОБРАЗОТВОРЧОЇ ДІЯЛЬНОСТІ
}

Анотація. У статті аналізується вплив різних видів образотворчої діяльності на творчий розвиток дітей старшого дошкільного віку. Представлено різні підходи до тлумачення ключових понять: «творчість» (зокрема, художня творчість, яка трактується як вища форма естетичної діяльності), «творчі здібності», «творча уява». Схарактеризовано поняття дитячої творчості, якому притаманні такі особливості, як: спонтанний характер; зв’язок з ігровою діяльністю; отримання необхідної інформації або вражень про відповідний об'єкт чи явище; відсутність нав'язливого впливу дорослих. Визначено критерії розвитку творчої уяви, зокрема такі, як уміння передавати форму предмета, володіння різними техніками малювання, демонстрування емоційного ставлення до створюваного образу через добір кольорової гами малюнка, уміння правильно розміщати композицію предметів на аркуші, емоційність створеного образу, предмета або явища, розробленість змісту зображення, динамічність художнього образу. Розкрито характеристику творчих здібностей, а також перелічено чинники, що стримують їх розвиток. Установлено, що образотворча діяльність значною мірою впливає на розвиток творчості дітей старшого дошкільного віку. Проаналізовано програму розвитку дітей старшого дошкільного віку «Впевнений старт» та програму розвитку дитини дошкільного віку «Українське дошкілля». Схарактеризовано вплив малювання на розвиток творчості дітей дошкільного віку, наголошено на необхідності використання різних технік малювання (малювання воском, засипання кухарською сіллю, малювання сухим пензлем по вологому тлі тощо); розкрито особливості ліплення старших дошкільників та його вплив на емоційно-почуттєву сферу дитини; проаналізовано роботу над аплікацією та конструюванням.

Ключові слова: базовий компонент дошкільної освіти, програма розвитку дітей старшого дошкільного віку «Впевнений старт», програма розвитку дитини дошкільного віку «Українське дошкілля», творчість, творчі здібності, творча уява, образотворче мистецтво, малювання, ліплення, конструювання, аплікація.

\section{DEVELOPMENT OF CREATIVITY OF PRESCHOOL CHILDREN IN DIFFERENT TYPES OF EDUCATIONAL ACTIVITIES}

Abstract. The article analyzes the influence of various types of fine arts on the creative development of older preschool children. The article includes different approaches to the interpretation of key concepts: "creativity» (in particular, artistic creativity, which is interpreted as the highest form of aesthetic activity), "creative abilities", "creative imagination». The concept of children's creativity is characterized, which has such features as: spontaneous character; connection with game activity; getting the necessary information or impressions about the object or phenomenon; partial influence of an adult.

The criteria for the development of creative imagination are defined, such as the ability to convey the shape of the object, mastering various drawing techniques, demonstrating emotional attitude to the created image through the selection of the color gamut of the image, the ability to correctly place the composition of objects on a sheet, the emotionality of the created image, object or phenomenon, elaboration of the image, dynamic artistic image. The characteristics of creative abilities are revealed, as well as the factors that impede their development. It has been established that fine arts influence to a great extent the development of creativity of older preschool children. The programs of development of senior preschool children "Confident start» and the program of development of the preschool child «Ukrainian preschool» are analyzed. According to the program «Confident start» a number of tasks of visual activity are defined, which are realized by involving children in different types of visual activity: drawing; molding; applique; designing. Guided by the program «Ukrainian Preschool» the influence of drawing on the development of creativity of preschool children was characterized, the necessity of using different drawing techniques (drawing with wax, filling with cooking salt, drawing with a dry brush on a wet background, etc.); 
features of modeling of senior preschoolers and its influence on the emotional and sensual sphere of the child are revealed; work on application and design is analyzed.

Keywords: Basic component of preschool education, program of development of senior preschool children "Confident start», program of development of preschool child «Ukrainian preschool», creativity, creative abilities, creative imagination, fine arts, drawing, modeling, design, application.

\section{ВСТУП}

Постановка проблеми. Сучасні тенденції розвитку освіти зумовлюють потребу використання компетентнісного підходу у формуванні та підготовці фахівців, оскільки сучасний випускник повинен не лише оволодіти необхідними знаннями, а й зобов'язаний бути готовим до розв'язання нестандартних завдань, еміти оперативно реагувати на виклики в професійній діяльності, працювати на випередження. Відтак актуальним бачиться формування особистості компетентної, творчої та відповідальної. Важливим етапом у житті кожної людини є дошкільне дитинство - період, коли закладаються основи її становлення та подальшого формування, актуалізується необхідність розвитку всіх задатків дитини-дошкільника як необхідної умови становлення різнобічно розвиненої особистості.

Так, у Базовому компоненті дошкільної освіти України особливе значення відводиться розвитку творчих здібностей дітей дошкільного віку. Результатом оволодіння дошкільником мистецькою діяльністю є сприйняття дитиною себе як активного суб'єкта творчості, а також сформоване ціннісно-емоційне ставлення до рукотворного світу.

Аналіз наукових досліджень і публікацій. Вивчення психологічних аспектів творчого розвитку дітей дошкільного й молодшого шкільного віку відображено в дослідженнях Л. Венгера, В. Давидова, Д. Ельконіна, О. Запорожця та інших. На сучасному етапі проблема формування креативної та всебічно розвиненої особистості $€$ предметом вивчення великої плеяди вчених, а саме: А. Бєлєнької, Е. Бєлкіна, Н. Гавриш, А. Гончаренко, В. Кузьменко, С. Кулачківської, Н. Миропольської, Т. Піроженко, З. Плохій, Ю. Приходько, Г. Тарасенко та інших.

\section{МЕТА І ЗАВДАННЯ ДОСЛІДЖЕННЯ}

Мета статті полягає в тому, щоб проаналізувати теоретичні аспекти творчості дітей дошкільного віку. Завдання статті - розкрити вплив різних видів образотворчого мистецтва на розвиток творчості дошкільників.

\section{МЕТОДИ ДОСЛІДЖЕННЯ}

Використано методи узагальнення, синтезу та аналізу науково-методичної літератури.

\section{РЕЗУЛЬТАТИ ДОСЛІДЖЕННЯ}

Творчість - діяльність, яка спрямована на створення якісно нового продукту. Водночас діяльність може виступати як прояв творчості в будь-якій сфері: науковій, виробничо-технічній, художній, літературній тощо, тобто там, де створюється, відкривається й винаходиться щось нове. За твердженням О. Туриніної: «Творчість - процес культурної людської діяльності, за результатами якого зароджуються якісно нові матеріальні та духовні цінності. Творчість - уміння людини, яке спрямоване на створення за допомогою різних засобів чи матеріалів нової реальності, що задовольняє різноманітні потреби людської життєдіяльності» (Туриніна О., 2007, с. 29). Аналізуючи сфери прояву творчості, доходимо висновків, що вони є різноманітними, а саме: літературна творчість, музична творчість, усна народна творчість тощо.

Окремо доцільно зупинитися на проблемі художньої творчості, яка пов'язана з процесом естетичного сприйняття дійсності. Зокрема, за визначенням І. Молодушкіної, художня творчість - це «... одночасний процес своєрідного поглинання предмета художником і художника предметом, в результаті якого народжується вигаданий світ художнього образу, своєрідний посередник між реальним світом і читачем» (Молодушкіна І., 2012, с. 73).

У сучасній науковій літературі художня творчість трактується як вища форма естетичної діяльності. 3 цього приводу Н. Данько зазначає: «Художня творчість завжди невіддільне від творця. Художник реалізує себе через створюваний образ, домагається адекватності зображення. Творчий процес носить багаторівневий характер: він особистісний і безособистісний. Художня творчість вписується в існуючі в суспільстві стилі або напряму, спирається на пізнання й оцінку» (Данько Н., 2013, с. 2). Актуальною для нашого дослідження є думка Л. Виготського, який трактував творчість як постійного супутника дитячого розвитку, результатом якої є формування ініціативності й самостійності дітей, розвитку мислення, здатність до самовираження у творчому процесі. Також учений зазначав, що творчість дорослої людини значно відрізняється від дитячої творчості, оскільки остання є «натуральною» і «природною» і базується на даних від народження задатках і вищих психічних функцій.

Таким чином, під поняттям «творчість дітей старшого дошкільного віку» розуміємо сам процес створення образів казки, оповідання, ігор-драматизації в малюванні тощо, пошуки шляхів розв'язання завдання в процесі образотворчої, ігрової або музичної діяльності.

Результати аналізу поняття дитячої творчості дозволяють виокремити такі їі особливості: дитяча творчість зазвичай непередбачувана і спонтанна; дитяча творчість здебільшого пов'язана з грою, яка є провідним видом діяльності дитини дошкільного віку; для реалізації дитячої творчості потрібно такі умови, за яких дитина буде почуватися вільною від впливу дорослих; для творчої (і для інших видів) діяльності дитини характерним є прагнення отримати вичерпну інформацію про певний предмет чи явище і повною мірою задовольнити свою допитливість тощо. 
Значення дитячої творчості полягає в тому, що в процесі й у результаті цієї діяльності дитина отримує такий універсальний розвиток, який має велике значення для життєдіяльності дошкільника і в якому зацікавлена не лише сім'я зокрема, але й суспільство загалом.

Одним з показників творчості є творча уява - «психічний процес створення нових образів, уявлень і думок на основі наявного досвіду, шляхом перебудови уявлень людини» (Павелків Р., 2008); «уява - це процес уявного перетворення реальності, здатність до побудови нових цілісних образів дійсності шляхом переробки змісту сформованого практичного, чуттєвого, інтелектуального і емоційно-смислового досвіду» (Павелків Р., 2008). Різновидом уяви $є$ творча уява, яка «передбачає самостійне створення нових образів, які реалізуються в оригінальних і цінних продуктах діяльності» (Шульга Л., 1995, с. 219).

Дослідниця Т. Комарова окреслила такі критерії розвитку творчої уяви дітей старшого дошкільного віку: оригінальність, розробленість образу, продуктивність, якість виконання малюнка. Цікавими для нашого дослідження $€$ напрацювання В. Суржанської, яка запропонувала такі критерії рівня розвитку творчої уяви дітей старшого дошкільного віку: уміння передавати форму предмета, володіння різними техніками малювання, демонстрування емоційного ставлення до створюваного образу через добір кольорової гами малюнка, уміння правильно розміщати композицію предметів на аркуші, емоційність створеного образу, предмета або явища, розробленість змісту зображення, динамічність художнього образу (Суржанська В., 2007, с. 22).

Важливе місце у творчому розвитку дошкільників посідають творчі здібності. За І. Білою, творчі здібності - це вищий прояв активності людини, здатність створювати щось оригінальне та нове, тобто таке, що суперечить традиційним уявленням і підходам (Біла І., 2014, с. 11). Творчі здібності (за О. Кульчицькою) - це властивості дитини, які забезпечують створення нового й оригінального, нестандартне сприйняття звичайних речей крізь призму нових можливостей їх функціонування або включення як частини у нову систему, здатність продукувати значну кількість ідей.

Розвиток творчих здібностей потребує створення сприятливих умов, за яких дитина не буде відчувати впливу дорослого. Коли діти почуваються вільно й безтурботно, творчі рішення приходять невимушено. За умови прояву з боку дорослого зауважень, стримування та приниження особистості дитини творчі прояви практично не проявляються. Отже, важливою умовою творчості $€$ сприятливі психолого-педагогічні умови, за яких має реалізовуватися творча діяльність: якщо педагог та батьки систематично дбають про засоби розвитку творчості дітей, але водночас не нав'язують їм власні зразки та погляди.

У Програмі розвитку дошкільників «Українське дошкілля» (Програма розвитку дитини дошкільного віку «Українське дошкілля", 2017) вказано вікові можливості старших дошкільників в оволодінні образотворчою діяльністю. Характерним для цього вікового періоду $є$ те, що у дітей значно підвищується рівень самостійності до виконання робіт, а також проявляється інтерес до колективного виконання композицій. Діти демонструють фантазію, творче мислення, тому їхні роботи часто вирізняються оригінальністю.

У Програмі розвитку дітей старшого дошкільного віку «Впевнений старт» окреслено основні завдання образотворчої діяльності для дітей цього віку. 3-поміж них можна виокремити такі: розвивати здатність дитини емоційно сприймати прояви естетичного у світі природи, мистецтва, гри, міжособистісних взаємин, виражати свої емоції в різних видах образотворчої діяльності; ознайомлювати дітей з різними видами образотворчого мистецтва; сформувати загальні уявлення про архітектуру та декоративно-ужиткове мистецтво; дати уявлення про основні жанри живопису (пейзаж, портрет, натюрморт, казковий, побутовий, анімалістичний); вчити застосовувати різноманітні засоби художньої виразності (лінії, колір, штрихи, форму, пропорції, композицію тощо) (Програма розвитку дітей старшого дошкільного віку «Впевнений старт»).

Образотворча діяльність має свої особливості саме в період дошкільного дитинства тому, що в дітей розвивається творча активність, вони починають створювати творчі продукти власної діяльності.

У розвитку творчих здібностей дітей дошкільного віку неоціненне значення мають різноманітні види образотворчої діяльності: малювання; ліплення; аплікація; конструювання.

Схарактеризуємо їх більш докладно.

Малювання - вид образотворчої діяльності, де зображення створюється на площині за допомогою художніх матеріалів (Бєлєнька Г. В., Голота Н. М., \& Гончаренко А. М., 2009, с. 58). Дітей старшого дошкільного віку в опануванні образотворчою діяльністю (за програмою «Українське дошкілля») доцільно навчити самостійно тонувати папір, добирати кольорову гаму; ознайомлювати з різними техніками малювання (це способи створення нового, оригінального твору мистецтва, у якому гармонує все: і колір, і лінія, і сюжет), зокрема малювання воском (крона дерев, сніговик, сніжинки), засипання кухарською сіллю (сніг, роса), малювання сухим пензлем по вологому тлі тощо (Програма розвитку дитини дошкільного віку «Українське дошкілля», 2017).

Іншими словами, розвивається активність уяви, ї̈ гнучкість. Малюючи, дитина проявляє своє прагнення до пізнання навколишнього світу, за малюнком (до певної міри) можна з'ясувати рівень цього пізнання. Чим більше розвинені в дітей сприймання, спостережливість, чим ширший запас їх уявлень, тим повніше і точніше відображають вони дійсність у своїй творчості і тим яскравішими є їхні малюнки.

Розвитку здатності до оригінального виконання задуму сприяє малювання за темою музичних творів. Діти із задоволенням виконують завдання «Хто сховався в цьому музичному фрагменті?» або «Передай настрій музики за допомогою кольору і ліній», оскільки їхня уява обмежена в цьому випадку лише музикою, а фантазія дозволяє знайти в музичних фразах те, що є близьким у цей момент дитині.

Ліплення - вид образотворчої діяльності, де образ створюється не тільки на площині, а й у обсязі. Ліплення дозволяє зобразити предмети в тривимірному просторі. У старшому дошкільному віці дітей потрібно навчати ліпити 
з натури чи за уявою з цілого шматка пластиліну, використовуючи різні способи: конструктивний, комбінований, пластичний (Шульга Л. М., 1995, с. 18).

У процесі ліплення дитина може передати образи та силуети людини (ніс, рот на обличчі), тварин (шерсть), птахів (пір'я), фруктів, посуду тощо (за програмою «Українське дошкілля») (Програма розвитку дитини дошкільного віку «Українське дошкілля», 2017). Властивості використовуваних у ліпленні матеріалів дають змогу неодноразово змінювати форму, досягаючи бажаної виразності. Саме розвитку здатності передачі виразності образу в ліплення необхідно приділити особливу увагу в роботі з дітьми старшого дошкільного віку. Важливо, щоб дитина вміла виліпити не просто фігуру людини, а людини певного віку, героїв конкретної казки - Ріпку, Ведмедя, Лиса Микиту тощо.

Ліплення позитивно впливає на нервову систему дитини, викликає гарні емоції, цікавить і хвилює їі. у процесі ліплення кожна дитина старшого дошкільного віку відчуває цілий спектр різноманітних почуттів: радіє, якщо задумане виходить, і засмучується, якщо щось пішло не так. Зазвичай ліплення повністю переключає увагу дитини на процес діяльності, психологічно розвантажуючи їі.

Аплікація - створення образу через прикріплення окремих деталей зображення на фон. Займаючись аплікацією, діти вчаться вирізати з паперу різноманітні сюжети, візерунки, орнаменти, наклеювати їх на кольоровий фон. Діти вчаться акуратності, посидючості, освоюють основні прийоми вирізування, правила роботи з клеєм. На цьому етапі діти навчаються оздоблювати візерунками площини різних форм і готові образи, використовуючи український орнамент (Казакова Р. Г., Сайганова Т. И., \& Седова Е. М., 2005, с. 19).

Конструювання - створення виробів з різних конструкторів і матеріалів. Види матеріалів: папір, природний матеріал, конструктор, будівельний матеріал (з великогабаритних модулів), комп'ютерне моделювання, непридатний матеріал (Шульга Л. М., 1995, с. 23). До прикладу, у комплексній програмі розвитку, навчання та виховання дітей дошкільного віку «Соняшник» конструювання в старшій групі закладу дошкільної освіти повинно спрямовуватися на активізацію дітей до розширення знань про властивості матеріалів та їх конструкторські можливості, а також про інструменти й обладнання для заняття.

Отже, залучення дошкільників до різних видів образотворчої діяльності сприяє розвитку в дітей уміння фантазувати. Ураховуючи те, що в дітей старшого дошкільного віку досить добре вироблено аналітичне мислення, вони можуть виділяти як загальні ознаки, властиві предметам одного виду, так і індивідуальні особливості, що відрізняють один предмет від іншого. Таким чином відбувається створення нових цікавих образів.

Розглядаючи образотворчу діяльність із психологічної точки зору, доходимо висновків, що виріб дитини старшого дошкільного віку - це відображення їі думок і почуттів. Дошкільник, коли малює або ліпить, не лише здійснює образотворчу діяльність, а й певним чином розв'язує свої внутрішні проблеми: зменшує емоційне напруження, бореться зі страхом або долає почуття самотності, виконуючи задум роботи. Також дитина творчо розвивається, оволодіваючи новими способами вже знайомих видів образотворчої діяльності.

\section{ВИСНОВКИ ТА ПЕРСПЕКТИВИ ПОДАЛЬШИХ ДОСЛІДЖЕНЬ}

Дошкільний вік - це період, коли дитина легко та із зацікавленістю втілює різні творчі ідеї та пошуки, створюючи неймовірні образи, вироби. Саме образотворче мистецтво дає змогу дитині не лише реалізовувати свої творчі задатки та здібності, а й комплексно впливає на формування творчої, розвиненої особистості дошкільника, створюючи тим самим підґрунтя для подальшого її становлення і формування. Перспективи подальших досліджень убачаємо в аналізі проблеми підготови майбутніх фахівців до розвитку творчості дошкільників у різних видах образотворчої діяльності.

\section{СПИСОК ВИКОРИСТАНИХ ДЖЕРЕЛ}

Бєлєнька, Г. В., Голота, Н. М., \& Гончаренко, А. М. (2009). Розвиток дитини-дошкільника: сучасні підходи та освітні технології: монографія. Київ.

Біла, І. М. (2014). Психологія дитячої творчості. Київ: Фенікс.

Данько, Н. П. (2013). Розвиток творчих здібностей молодших школярів. Початкова школа, 4, 1-2.

Казакова, Р. Г., Сайганова, Т. И., \& Седова, Е. М. (2005). Рисование с детьми дошкольного возраста. Нетрадиционные техники, планирование, конспекты занятий. Москва: Сфера.

Молодушкіна, І. В. (2012). Розвиток креативних здібностей у дітей дошкільного віку. Харків: Вид. група «Основа».

Павелків, Р. В. (2008). Дитяча психологія: навч. посіб. Київ: Академвидав.

Програма розвитку дітей старшого дошкільного віку «Впевнений старт». URL: https://mon.gov.ua/storage/app/media/programyrozvytku-ditey/programavpevneniy-start.pdf

Програма розвитку дитини дошкільного віку «Українське дошкілля» / О. I. Білан, за заг. ред. О. Низьковської. (2017). URL: https://mon. gov.ua/storage/app/media/programy-rozvytku-ditey/Bilan_Programa_Ukrdoshkillja_2017.pdf

Рибалка, В. В. (2016). Словник із психології та педагогіки обдарованості і таланту особистості: термінологічний словник. Київ, Житомир: Вид-во жДУ ім. І. Франка.

Суржанська, В. А. (2007). Розвиваємо творчі здібності. Харків: Основа.

Туриніна, О. Л. (2007). Психологія творчості: Навч. посіб. Київ: МАУП.

Шульга, Л. М. (1995). Розвиток творчих здібностей дітей дошкільного віку на заняттях з малювання: Конспект лекцій і занять (за матеріалами власного досвіду). Київ: ІСДО. 


\section{REFERENCES}

Bielienka, H. V., Holota, N. M., \& Honcharenko, A. M. (2009). Rozvytok dytyny-doshkilnyka: suchasni pidkhody ta osvitni tekhnolohii: monohrafiia. Kyiv.

Bila, I. M. (2014). Psykholohiia dytiachoi tvorchosti. Kyiv: Feniks.

Danko, N. P. (2013). Rozvytok tvorchykh zdibnostei molodshykh shkoliariv. Pochatkova shkola, 4, 1-2.

Kazakova, R. H., Saihanova, \& T. Y., Sedova, E. M. (2005). Risovanie s detmi doshkolnoho vozrasta. Netraditsionnye tekhniki, planirovanie, konspekty zaniatii. Moskva: Sfera.

Molodushkina, I. V. (2012). Rozvytok kreatyvnykh zdibnostei u ditei doshkilnoho viku. Kharkiv: Vyd. hrupa "Osnova».

Pavelkiv, R. V. (2008). Dytiacha psykholohiia : navch. posib. Kyiv: Akademvydav.

Prohrama rozvytku ditei starshoho doshkilnoho viku «Vpevnenyi start». Retrieved from: https://mon.gov.ua/storage/app/media/programy-rozvytkuditey/programavpevneniy-start.pdf

Prohrama rozvytku dytyny doshkilnoho viku «Ukrainske doshkillia» / O. I. Bilan, za zah. red. O. Nyzkovskoi (2017). Retrieved from: https://mon.gov. ua/storage/app/media/programy-rozvytku-ditey/Bilan_Programa_Ukrdoshkillja_2017.pdf

Rybalka, V. V. (2016). Slovnyk iz psykholohii ta pedahohiky obdarovanosti i talantu osobystosti: terminolohichnyi slovnyk. Kyiv, Zhytomyr: Vyd-vo ZhDU im. I. Franka.

Surzhanska, V. A. (2007). Rozvyvaiemo tvorchi zdibnosti. Kharkiv: Osnova.

Turynina, O. L. (2007). Psykholohiia tvorchosti: Navch. posib. Kyiv: MAUP.

Shulha, L. M. (1995). Rozvytok tvorchykh zdibnostei ditei doshkilnoho viku na zaniattiakh z maliuvannia: Konspekt lektsii i zaniat (za materialamy vlasnoho dosvidu). Kyiv: ISDO.

Статтю подано до редколегії 12.09.2019 p.

Рекомендовано до друку $\quad 02.10 .2019$ p. 